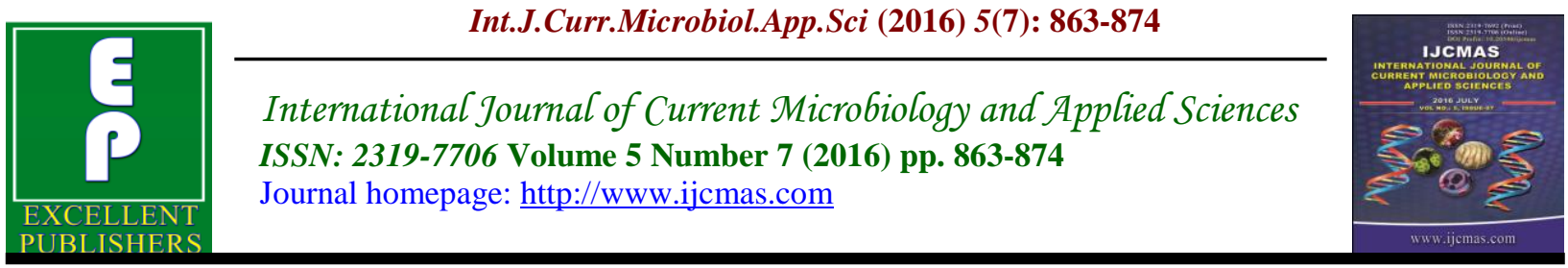

Original Research Article

http://dx.doi.org/10.20546/ijcmas.2016.507.099

\title{
Screening, Production and Industrial Application of Protease Enzyme from Marine Bacteria
}

\author{
Hala Ezzat Abou El-Hassayeb ${ }^{1^{*}}$ and Samaa M.Z. Abdel Aziz ${ }^{2}$ \\ ${ }^{1}$ Department of Marine Microbiology, National Institute of Oceanography and \\ Fisheries, Alexandria, Egypt \\ ${ }^{2}$ Head of Industrial Wastewater Research, Department, ASDCO, Egypt \\ *Corresponding author
}

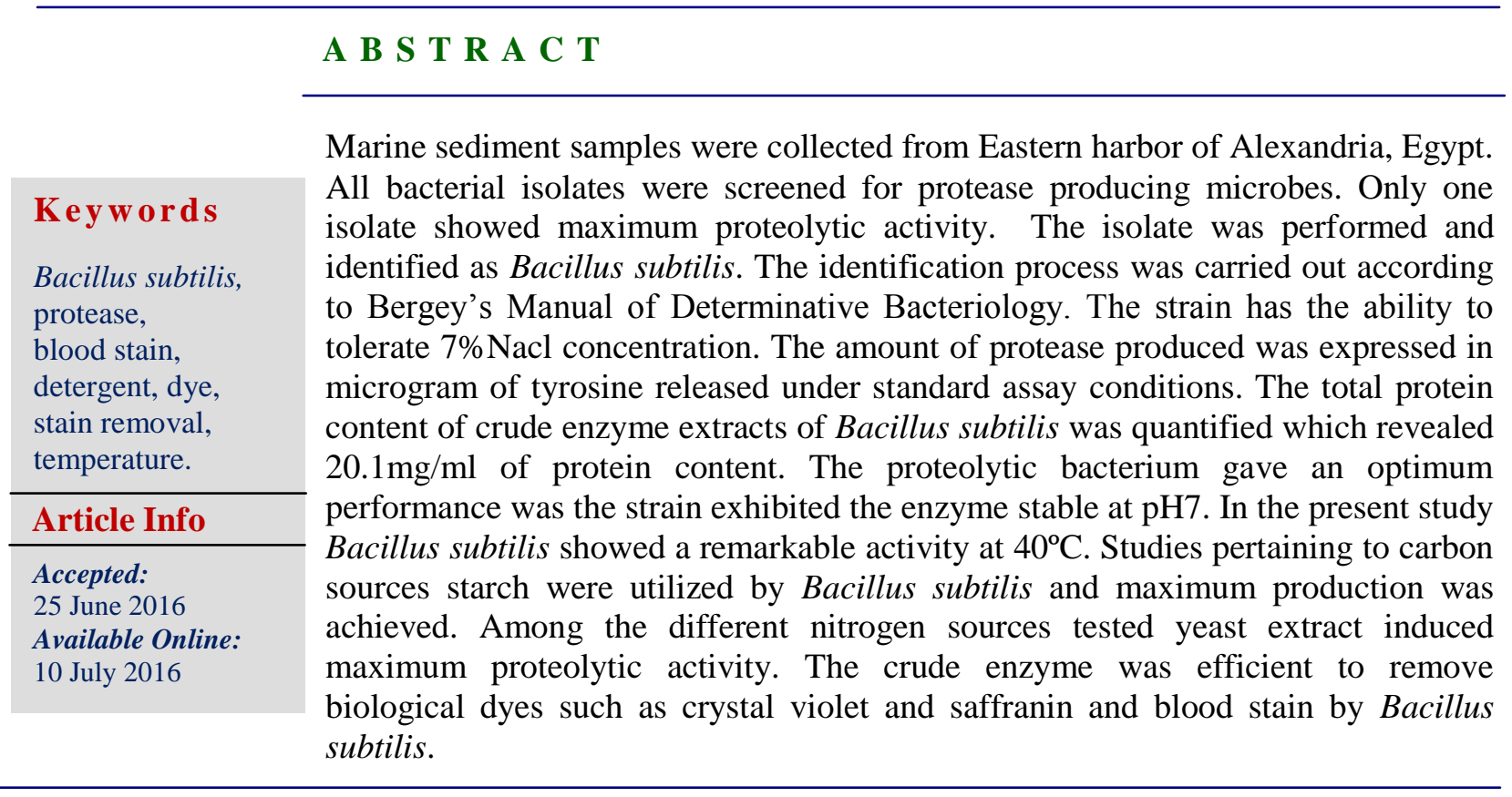

\section{Introduction}

Marine organisms were used to modify products, to improve plants or animals or to develop microorganisms for specific uses (Jha et al., 2004). There has been a tremendous interest from researchers to explore marine microorganisms as new source of antibacterial compounds as increasing resistance of pathogen to present antibiotics. Marine microorganisms were proven already to have many beneficial bioactivities such as production of industrial enzymes (Chatellier et al., 2000). Bacteria were isolated and cultivated from all possible regions of the earth, on the basis of their habitat, diversity, ecological functions, degree of pathogenicity and biotechnological applications. $70 \%$ of the earth's surface is covered by oceans with rich microbial diversity. About $3.6 \times 1029$ microorganisms were found in marine environments, including subsurface and harbor (Sogin et al., 2006). Marine microbes 
were now being looked upon as a potential source of various compounds; pharmaceutical, nutritional supplements, agrochemicals, cosmetics and enzymes (Vignesh et al., 2011). Proteases were a group of enzymes, whose catalytic function are to, hydrolyse peptide bonds of proteins and break them down into polypeptides or free amino acids. They constitute $59 \%$ of the global market of industrial enzymes, which is expected to exceed $\$ 2.9$ Billion by 2012 . (Jon, 2008).

Proteolytic enzymes were degradative enzymes which catalyze the cleavage of peptide bonds in other proteins. Alkaline proteases, which are referring to proteolytic enzymes which work optimally in alkaline $\mathrm{pH}$ are the main enzymes among proteases and constitute 60 to $65 \%$ of the global industrial enzyme market (Amoozegara et al., 2004). It has wide range of commercial usages in detergents, leather, food and pharmaceutical industries (Deng et al., 2010). The genus "Bacillus" is an important source of industrial proteases and were probably the only genera being commercialized for alkaline protease production (Kocher, 2009). Many Bacillus species produce a variety of extracellular and intracellular proteases. Protease constitutes a large and complex group of enzymes that play an important nutritional and regulatory role in nature.

Proteases were (Physiologically) necessary for living organisms, and they are ubiquitous and found in a wide diversity of marine sources. Marine microbial enzymes have unique catalytic properties due to their distinct physiological and metabolic characteristics, efficient nutrient utilization in oligotrophic waters etc. and are also the source of novel biocatalysts like cold adapted enzymes which are economical in terms energy savings (Shanmuga Priya et al., 2008).

\section{Materials and Methods}

\section{Isolation of Marine Bacteria from Marine Sediments}

Marine sediment samples were collected from Eastern harbor of Alexandria, Egypt and screened for protease producing microbes. The collection was performed in plastic containers and transferred to laboratory at room temperature and the process of isolation was initiated immediately.

\section{Screening for Protease Enzyme}

The isolated colonies were screened for protease production using skim milk agar medium. All the isolates were streaked on to skim milk agar plates and the plates were incubated for $48 \mathrm{~h}$ at $37^{\circ} \mathrm{C}$. The clear zone around the streak of bacteria was evaluated as protease producers.

\section{Characterization of the Effective Protease Producing Isolates}

The bacterial isolate with prominent zone of clearance around the streak of bacterial isolate and showing efficient enzyme production was processed for the determination of colony morphology, Gram staining, biochemical tests and enzyme profiles and then identified in accordance with the Bergey's Manual of Determinative Bacteriology.

\section{Identification and Characterization of Isolated Organisms}

The protease producing marine bacterium was identified based on morphological and biochemical characterization.

\section{Production of Protease Enzyme}

For enzyme production media consisting of 
Casein $-2.0 \%$, Dextroses- $1.0 \%$, Peptone $1.0 \%, \mathrm{KH} 2 \mathrm{PO} 4-2.0 \%, \mathrm{NaCl} 2-0.2 \%$, $\mathrm{CaCl} 2-0.002 \%$ at $\mathrm{pH} 7.0$ was used. Inoculums (OD $660 \mathrm{~nm}$ ) were developed by growing the isolate in nutrient broth for 24 h. For production of enzyme, $1.0 \%$ inoculums was added to $50 \mathrm{ml}$ production medium in $250 \mathrm{ml}$ conical flasks and then incubated at $37^{\circ} \mathrm{C}$ for $3-4$ days. Sample withdrawn at specific time intervals were centrifuged at 5,000 rpm for $20 \mathrm{~min}$ and the supernatant has been used as enzyme source for assay.

\section{Quantitative Estimation of Protein}

The quantitative estimation of protein was determined by the method Lowry's (Lowry et al., 1951) using bovine serum albumin as the standard.

\section{Determination of Molecular Weight of Protein in SDS - PAGE}

The molecular weight of the crude enzyme was determined by sodium dodecyl sulphate Polyacrylamide gel electrophoresis (SDSPAGE) (Laemmli et al., 1970).

\section{Protease Enzyme Assay}

Proteolytic activity was carried out according to casein - pholine method culture media was centrifuged at $7200 \mathrm{rpm}$ for 10 min and supernatant was used as enzyme source. However, $1 \%$ Casein (in $0.1 \mathrm{M}$ phosphate buffer and $\mathrm{pH}$ 7.0) was used as substrate. $1 \mathrm{ml}$ each of enzyme and substrate was incubated at $50^{\circ} \mathrm{C}$ for $60 \mathrm{~min}$. The reaction was terminated by adding $3 \mathrm{ml}$ of Trichloroacetic acid (TCA).

One unit of protease activity was defined as the increase of 0.1 unit optical density at $1 \mathrm{~h}$ incubation period. It was then centrifuged at $5000 \mathrm{rpm}$ for $15 \mathrm{~min}$. From this, $0.5 \mathrm{M}$ of supernatant was taken, to this $2.5 \mathrm{ml}$ of 0.5
M sodium carbonate was added, mixed well and incubated for $20 \mathrm{~min}$. Then it was added with $0.5 \mathrm{ml}$ of folin phenol reagent and the absorbance was read at $660 \mathrm{~nm}$ using spectrophotometer. The amount of protease produced was estimated and expressed in microgram of tyrosine released under standard assay conditions. Based on the tyrosine released the protease activity was expressed in microgram of tyrosine released by $1 \mathrm{ml}$ of enzyme in 30 minutes at $30^{\circ} \mathrm{C}$ on tyrosine equivalent.

\section{Optimization Parameters for Protease Enzyme Production}

\section{Effect of Temperature on Enzyme Activity}

The influence of different temperature on proteolytic activity of the crude enzyme was determined by holding the reaction mixture at various temperatures $\left(30^{\circ} \mathrm{C}, 40^{\circ} \mathrm{C}, 50^{\circ} \mathrm{C}\right.$, $60^{\circ} \mathrm{C}$, and $70^{\circ} \mathrm{C}$ ) for 30 min during standard enzymes assay.

\section{Effect of pH on Enzyme Activity}

To optimize the $\mathrm{pH}$ of enzyme activity, $1 \mathrm{ml}$ of enzyme solution was reacted with $5 \mathrm{ml}$ of casein solution $(1 \%(\mathrm{w} / \mathrm{v}))$ in various $\mathrm{pH}$ values $(4,5,6,7,8,9$, and 10$)$ at $37^{\circ} \mathrm{C}$ for 30 min and the enzyme activity was assayed.

\section{Effect of Nitrogen Sources on Enzyme Production}

To optimize the nitrogen source for enzyme production, five different nitrogen source (1\%) (Urea, Gelatin, Casein, Ammonium chloride and Yeast extract) were added to nutrient broth and the organism was inoculated and incubated for $48 \mathrm{~h}$ at $37^{\circ} \mathrm{C}$. The enzyme activity was assay in the culture supernatant. 


\section{Effect of Carbon Sources on Enzyme Production}

To find the optimum carbon source for enzyme production, five carbon source (1\%) (Xylose, Glucose, Starch, Lactose and Sucrose) were supplemented to nutrient broth the organism was inoculated and incubated for $48 \mathrm{~h}$ at $37^{\circ} \mathrm{C}$ and the enzyme activity was assayed in the culture supernatant.

\section{Application of Protease Enzyme: Wash Performance Test}

Stability of the protease in commercial detergents was tested by incubating measured quantity of the enzyme $(500 \mu l)$ with the solutions of the different commercial detergent concentration of 7 $\mathrm{mg} / \mathrm{ml}$ (to simulate washing conditions) for 1h. The detergents tested were Ariel, Tide and Persil, which are widely used in Egypt. Suitable aliquots were drawn at different time intervals (at15, 30 and $60 \mathrm{~min}$ ), for $1 \mathrm{~h}$, and their activity was measured by standard assay procedure and compared with the control (incubated under similar conditions, without any detergent) and the relative activity was expressed in \% taking the value given by control as $100 \%$. Application of protease as a detergent additive was studied on white cotton cloth pieces $(4 \times 5 \mathrm{~cm})$ stained with crystal violet $(0.1 \%)$, saffranin $(0.1 \%)$ and blood stain.

The stained cloth pieces were taken in separate flasks. The following sets were prepared:

a. Flask with distilled water $(100 \mathrm{ml})+1 \mathrm{ml}$ stained cloth (crystal violet $(0.1 \%)$ saffranin $(0.1 \%)$ and blood).

b. Flask with distilled water $(100 \mathrm{ml})+1 \mathrm{ml}$ detergent $(7 \mathrm{mg} / \mathrm{ml})$. c. Flask with distilled water $(100 \mathrm{ml})+1 \mathrm{ml}$ detergent $(7 \mathrm{mg} / \mathrm{ml})+2 \mathrm{ml}$ enzyme solution.

\section{Results and Discussion}

\section{Isolation and Screening of Protease Producing Microorganisms}

In the present study, different marine sediment samples were collected from Eastern harbor of Alexandria, Egypt. The samples were serially diluted, spread plated and incubated at $37^{\circ} \mathrm{C}$ for $48 \mathrm{~h}$. About four dominant morphologically distinct colonies were selected and pure cultured by repeated streaking on the nutrient agar plates. The four isolated bacterial strains were screened for protease producing ability on skim milk agar. The zone formation around the streak of bacterial growth was identified as the positive protease producers which may be due to hydrolysis of casein. Among the four isolates screened, only one isolate showed a proteolytic activity with a zone of clearance around the streak of the isolate (Figure 1). Therefore, this efficient protease producing strain was selected for further experimental studies and biochemical tests.

\section{Identification of the Efficient Marine Protease Producing Strain}

Morphological (Table1) and biochemical characterization were performed in accordance was Bergey's manual of determinative bacteriology methods. It was identified as Bacillus subtilis.

\section{Salt Tolerance of the Isolate}

The salt tolerance of the isolate was studied at various $\mathrm{NaCl}$ concentrations such as $3 \%$ $\mathrm{NaCl}, 4 \% \mathrm{NaCl}, 5 \% \mathrm{NaCl}, 6 \% \mathrm{NaCl}$, and $7 \%$ $\mathrm{NaCl}$. The results were shown in (Figure 2). It was found that the tested strain has the ability to tolerate up to $7 \% \mathrm{NaCl}$ concentration. 


\section{Protease Enzyme Assay}

Crude enzyme extract was studied for protein degrading activity and the amount of amino acid produced was measured by using Folin phenol reagent and the absorbance was read at $660 \mathrm{~nm}$ using colorimeter. The amount of protease produced was estimated and expressed in microgram of tyrosine released under standard assay conditions. Based on the tyrosine released the protease activity was expressed in microgram of tyrosine released by $1 \mathrm{ml}$ of enzyme in 30 $\min$ at $30^{\circ} \mathrm{C}$ on tyrosine equivalent.

\section{Determination of Total Protein Content}

The total protein content of crude enzyme extracts from Bacillus subtilis was quantified by Lowry et al., method with BSA standard. It was found out that Bacillus subtilis revealed $20.1 \mathrm{mg} / \mathrm{ml}$.

\section{Determination of Molecular Weight by SDS - PAGE}

The molecular weight of purified enzyme was determined by SDS - PAGE. The crude protease enzyme was concentrated by centrifugation and approximately $90-100 \%$ of proteolytic activity was observed. Determination of molecular weight by SDSPAGE for the separated fractions of the protease enzyme exhibited a predominant peak (band) of $28 \mathrm{kDa}$ which indicate that protease have high activity and this lyse within the molecular weight range of standard marker between 14-160kDa protein marker (Figure3).

\section{Effect of Temperature on Protease Enzyme Activity}

Temperature also played an important role in activating and inactivation of enzymes. In the present study, the effect of temperature on protease production was studied with various temperatures ranging from 30 $70^{\circ} \mathrm{C}$. The protease activity is relatively stable in the temperature range $40^{\circ} \mathrm{C}$ for Bacillus subtilis $(0.232 \mathrm{U} / \mathrm{ml})$.). The enzyme activity was found to be decreased above and below those temperatures for both strains. The present investigation showed that Bacillus subtilis produced maximum protease at $40^{\circ} \mathrm{C}$. The obtained results were noted in (Figure 4).

\section{Effect of pH on Protease Enzyme Activity}

$\mathrm{pH}$ played an important role in the enzyme production. In the present study the $\mathrm{pH}$ optima of protease activity was studied at different $\mathrm{pH}$ ranging from 4 to 10 . The highest protease production was observed in pH 7 for Bacillus subtilis with $0.174 \mathrm{U} / \mathrm{ml}$. Below and above that $\mathrm{pH}$ the enzyme activity was found to be decreased. The obtained results were presented in (Figure $5)$.

\section{Effect of Nitrogen Sources On Protease Activity}

In the present investigation, urea, gelatin, casein, ammonium chloride and yeast extract were added in the medium for determining protease activity. Among the different nitrogen sources tested maximum protease production was observed at yeast extract with $0.213 \mathrm{U} / \mathrm{ml}$ for Bacillus subtilis. The addition of other nitrogen sources caused a drastic reduction in enzyme activity. These results were noted in (Figure $6)$.

\section{Effect of Carbon Sources On Protease Activity}

The effect of different carbon sources viz. Xylose, Glucose, Starch, Lactose and Sucrose on enzyme activity was studied. 
Maximum protease production was observed in Bacillus subtilis when starch $(0.270 \mathrm{U} / \mathrm{ml})$ was supplemented as carbon source. The least enzyme activity was observed in Lactose $(0.157 \mathrm{U} / \mathrm{ml})$. The results were presented in (Figure 7).

\section{Application of the Protease Enzymes in Stain Removal}

In order to find out the dye removal efficacy of the dyes and strain, a white cotton cloth $(4 \times 5 \mathrm{~cm})$ was stained with crystal violet $(0.1 \%)$, saffranin $(0.1 \%)$ and dried in hot air oven for $2 \mathrm{~h}$. Then the stained cloth was incubated at $50^{\circ} \mathrm{C}$ in enzyme broth for different time intervals. The enzyme was able to remove crystal violet $(0.1 \%)$, saffranin $(0.1 \%)$ from the test fabric cloth after 2 hours at $50^{\circ} \mathrm{C}$. These results were noted in (Figure ). The enzyme was also efficient to remove blood stain within 30 minutes. It was seen that protease produced by Bacillus subtilis had high capability of removing the dye and blood stain from fabric cloth, which indicated its potential in detergent industries. The obtained results were noted in (Figure 8)

From the present study it is revealed that the protease enzyme produced by Bacillus subtilis showed a positive result in the removal of dye and blood stain from the cloth. Therefore this enzyme was used in the industrial applications in pilot scale.

Proteases from microbial sources are preferred than the enzymes obtained from plant and animal sources since they possess almost all characteristics desired for their biotechnological applications. Proteolytic bacteria are wide spread in nature and are able to grow under various growth conditions, such as different temperatures, $\mathrm{pH}$ and ionic strength (Sanchez-Porro et al., 2003). The bacteria that exist in the marine samples represent a very important and diversified enzymatic potential. But sufficient information is not much available on their role in industrial and hence the present study was carried to isolate and characterize the potent protease positive bacteria from the marine sediment sample of Eastern Alexandria Harbor (Egypt).It has been reported that the production of extracellular proteases by different microorganisms can be strongly influenced by the culture conditions. So, it becomes necessary to understand the natural proteases and their catalytic potentiality under different conditions. (Johnvely et al., 2002). In this experiment, one bacterial isolate from the four bacterial isolates was able to produce proteolytic enzymes by formation of clear zone on skim milk around the peak of bacterial as indication of good growth with the ability of protease production (Boominadhan et al., 2009). Determination of molecular weight by SDSPAGE for the separated fractions of the protease enzyme exhibited a predominant peak (band) of $28 \mathrm{kDa}$ which indicate that protease have high activity and this lyse within the molecular weight range of standard marker between 14-160kDa protein marker. Our results are in total agreement with the work of which emphasized that protease fractions of appeared as a single band just below $28 \mathrm{kDa}$ isolated from B.species. It is concluded that B. subtilis capable of producing proteolytic enzyme giving optimum performance and serves to be an ideal potential candidate for industrial applications. The enzyme was considerably stable at $\mathrm{pH} 7$ for the strain, but below and above that $\mathrm{pH}$ the enzyme stability gradually decreased. Similar results were reported by (Abu Sayem Alam et al., 2006). The present observations disagreed with the results of in which they reported that Bacillus sp was highly active and stable at pH 9-10 (Abou Elalla et al., 2009) reported that optimum 
protease activity and stability was recorded at $\mathrm{pH}$ 9-9.5. Temperature plays an important role in inactivation and activation of enzymes. Each enzyme has an optimum temperature for maximum enzyme activity. In the present study, Bacillus subtilis showed maximum activity at $40 \mathrm{oC}$. Our results coincide with the work of in which he demonstrated that at temperatures of 60 and $70 \mathrm{oC}$, the enzyme lost its activity rapidly whereas the optimum temperature were found to be $40 \mathrm{oC}$.

Table.1 Morphological and Physiological Characterization of the Efficient Protease Producing Isolate

\begin{tabular}{|c|c|}
\hline Tests & Bacillus subtilis \\
\hline Colony morphology & $\begin{array}{c}\text { On nutrient agar, it } \\
\text { produced creamy white, } \\
\text { irregular undulate colonies. }\end{array}$ \\
\hline $\begin{array}{c}\text { Morphological } \\
\text { characteristics. } \\
\text { a) Gram staining } \\
\text { b) Spore staining }\end{array}$ & $\begin{array}{c}\text { Positive rod } \\
\text { Endospore forming }\end{array}$ \\
\hline
\end{tabular}

Fig.1 Screening of marine bacterial isolates for proteolytic activity in skim milk agar

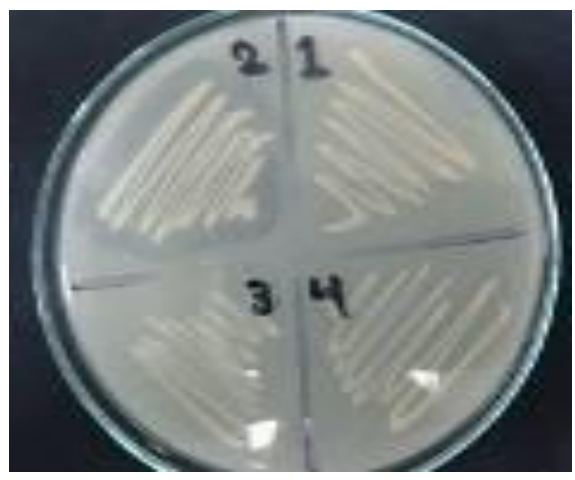

Fig.2 The tested strain has the ability to tolerate $6 \% \mathrm{NaCl}$ concentration. Protein profile of the crude protease of Bacillus subtilis in SDS-PAGE

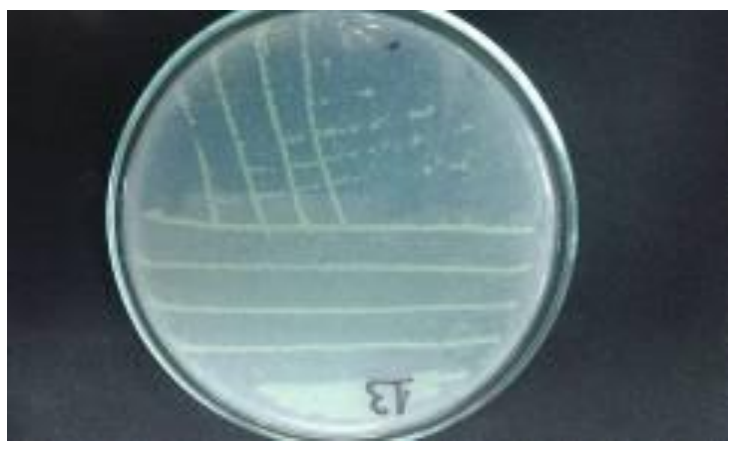


Fig.3 Protein profile of the crude protease of Bacillus subtilis in SDS-PAGE Lane1: Marker protein and Lane 2\&3: Bacillus subtilis crude protease (28 kDa)

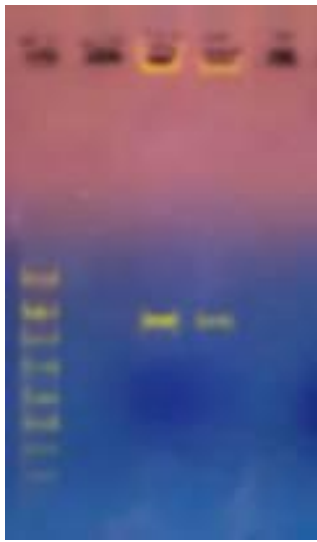

Fig.4 Effect of pH on Protease Enzyme Activity
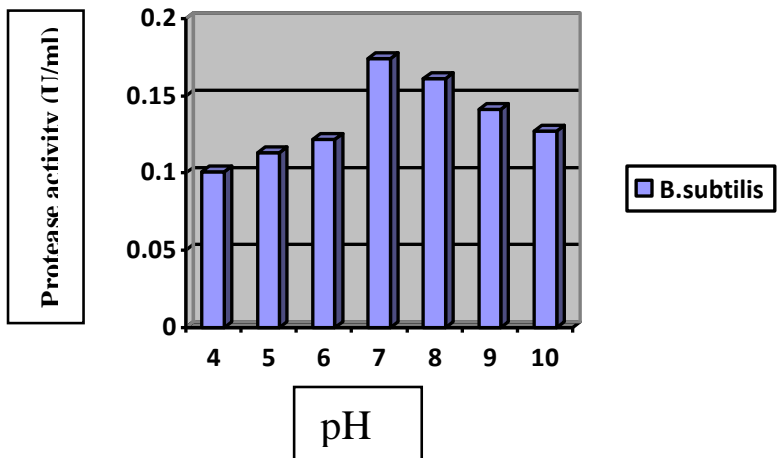

Fig.5 Effect of temperature on Protease Enzyme Activity
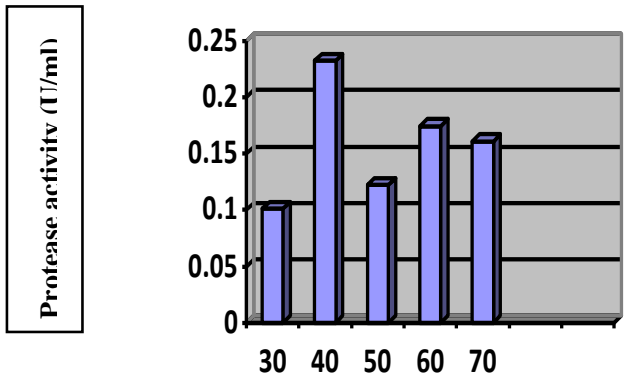

QB.subtilis

temperature 
Fig.6 Effect of Carbon Source on Protease Enzyme Activity

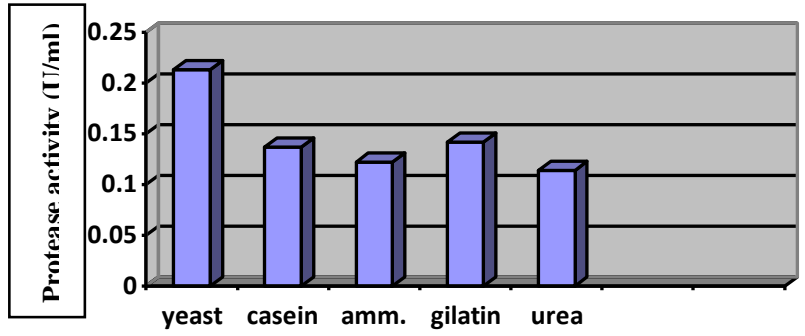

\section{Carbon Source}

Fig.7 Effect of Nitrogen Source on Protease Enzyme Activity

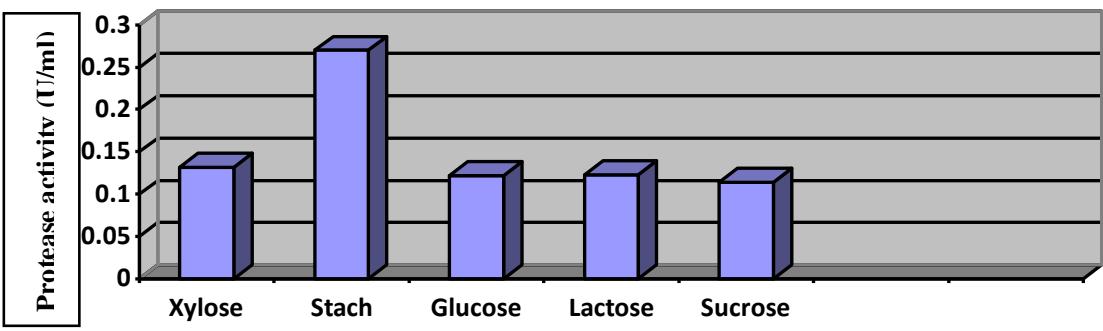

\section{Nitrogen Source}

Fig.8 Effect of Bacillus subtilis protease on crystal violet dye and blood stain Removal at 500C
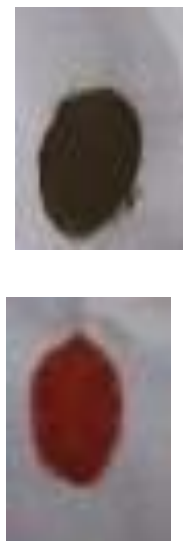

Dist. Water

$+$

Stained cloth
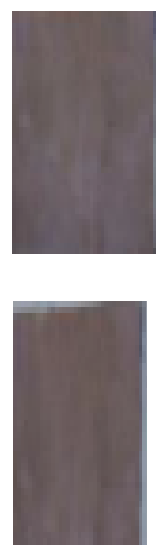

Dist. Water

$+$

Detergent
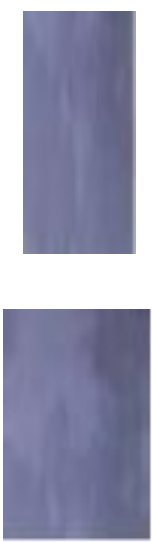

dist. Water

$+$

Detergent

$+$

Enzyme solution 
The results of the present study agreed with the mentioned results of (Nehra et al., 2002). The addition of carbon sources in the medium influence the production of protease enzyme. Maximum production was observed in starch for B.subtilis. It is worthy to note that except starch, the addition of other carbon sources in the production medium led to the remarkable decreases in protease production. These results are in accordance with the finding of (Srinivas Naik et al., 2013). The nitrogen sources are the secondary energy sources for microorganisms which play an important role in the growth of the organisms and enzyme production. In the presence study, the extra addition of yeast extract to the medium induced the proteolytic activity. The other sources showed no remarkable increase or depressive effective on protease production. Similar work was carried out by (Feroz Khan, 2013).

In laundry detergent, the use of enzymes such as proteases in very common about $50 \%$ of liquid detergent, $25 \%$ of powder detergent had almost all powder bleach additives now contain enzymes to help in breaking down of stains that are otherwise hard to remove with conventional surfactants alone. They work as scissors to cut off the stain physand piece by piece from the surface of the fabrics (Panagal Mani et al., 2012). The efficiency of B.subtilis protease was tested for removing the blood stain and crystal violet $(0.1 \%)$, saffranin $(0.1 \%)$ dye from test fabrics at $50^{\circ} \mathrm{C}$ with enzymes and $1 \% \mathrm{~V} / \mathrm{V}$ of $15 \mathrm{mg} / \mathrm{ml}$ detergents (Tide). The enzyme was efficient to remove blood stain within 30 minutes. The enzyme was also able to remove dye within $2 \mathrm{~h}$ and also showed computability with the detergents the protease enzymes were also used as an additive detergent to check the contribution of the enzymes in improving the washing performance of the detergents.
The supplementation of the enzyme preparation in Tide could significant improving \& cleansing performance towards proteinase stain (blood stain \& dye).

In conclusion, proteases are important enzymes obtained from marine microorganisms which synthesis bioactive compounds. The bacterial strain isolated from marine environment where identified as Bacillus subtilis. Screening was performed and maximum proteolytic activity was revealed. Bacillus subtilis has tolerated up to $7 \% \mathrm{NaCl}$ concentration. Whereas optimization of $\mathrm{pH}$ revealed that Bacillus subtilis exhibited to increase protease production at $\mathrm{pH} 7$. Different carbon sources tested starch was found suitable for protease. Similarly supplementation of nitrogen sources was found favorable for Bacillus subtilis utilized yeast extract as nitrogen source. Molecular analysis of the crude enzyme showed prominent band with the molecular weight of $28 \mathrm{Kda}$. The role of protease enzyme in wash performance using detergent was found to hydrolysed large protein molecules associated with hard dyes and stain. Hence it is imperative to use the crude protease enzyme for stain removal.

\section{Acknowledgement}

Sincerely thanks to Marine Microbiology $\mathrm{Lab}$ at the National Institute of Oceanography and Fisheries, Alexandria, Egypt. The author thanks his respective managements for encouragement, facilities and support.

\section{References}

Jha, R.K., X. Zi-rong. 2004. Biomedical compounds from marine organisms. $J$. Marine drugs, 2(3): 123-146.

Chatellier, S., N. Ihendyane, R.G. Kansal, F. Khambaty, H. Basma, A. NorrbyTeglund. 2000. Genetic relatedness 
and super antigen expression in group A streptococcus serotype M1 isolates from patients with severe and nonsevere invasive diseases, Infect. Immun., 68: 3523-3534.

Sogin, M.L., H.G. Morrison, J.A. Huber, D.M. Welch and S.M. Huse. 2006. Microbial diversity in the deep sea and the underexplored "rare biosphere", PNAS, 103: 12115-12120.

Vignesh, S., A. Raja and R.A. James. 2011. Marine drugs: Implication and future studies, Int. Jr. Pharmaco., 7: 22-30.

Jon, S. 2008. Global Industry Analysts, www.theprofitdepot.com.

Amoozegara, M.A., A.Z. Fatemia, H.R. Karbalaei- Heidarib, and M.R. Razavic. 2007. Production of an extracellular alkaline metalloprotease from a newly isolated, moderately halophilic, Salinivibrio sp. strain AF2004, Microbiol. Res, 162: 369-377.

Deng, A., W.U.J. Zhang, Y. Zhang, G. Wen. 2010. Purification and characterization of a surfactant-stable high-alkaline protease from Bacillus sp. B001, Bioresource. Technol., 101: 71007116.

Kocher, G.S., S. Mishra. 2009. Immobilization of Bacillus circulans MTCC 7906 for enhanced production of alkaline protease under batch and packed bed fermentation conditions, Internet J. Microbiol., 7: 2.

Sana, B., D. Ghosh, M. Saha and J. Mukherjee. 2006. Purification and characterization of a salt, solvent, detergent and bleach tolerant protease from a new gamma-Proteobacterium isolated from the marine environment of the Sundarbans, Process. Biochem., 41: 208-215.

Shanmuga Priya, S., J. Krishnareni, Joseph Selvin, R. Gandhimathi, M. Arun Kumar, T. Thangavelu, G. Seghal Kiran, K. Nataraja seenivasan. 2008.
Optimization of extracellular thermo tolerant alkaline protease produced by marine Roseobacter Sp (MMD040), Bioprocess Biosyst Eng, 31: 427-43.

Ishikawa, H., K. Ishimi, M. Sugiura, A. Sowa, and N. Fujiwara. 1993. Kinetics and mechanism of enzymatic hydrolysis of gelatin layers of X-ray film and release of silver particles. $J$. Fermentation and Bioengi., 76(4): 300-305.

Lowry, O.H. N.J. Rosebrough, A.L. Farr, and R.J. Randall. 1951. Protein measurement with the Folin phenol reagent, J. Biol. Chem., 93: 265-275.

Laemmli, U.K. 1970. Cleavage of structural proteins during assembly of head of bacteriophage T4 Nature, 227: 680685.

Cappuccino, J.G., N. Sherman. 2002. Microbiology: A laboratory manual. Pearson Education, 6 (4): 21-23. 15.

Gupta, R.Q., K. Beg and P. Lorence. 2002. Bacterial alkaline protease: molecular approaches and industrial applications, Appl. Microbiol. Biotechno., 59: 1520.

Sanchez-Porro, C., E. Mellado, C. Bertoldo, G. Antranikian, A. Ventosa. 2003. Screening and characterization of the protease $\mathrm{CP} 1$ produced by the moderately halophilic bacterium Pseudoalteromonas sp strain CP76, Extremophiles, 7: 221-8.

Johnvely, B., B.R. Manjunath, and G.R. Naik. 2002. Pigeon pea waste as a novel, inexpensive, substrate for production of a thermo stable alkaline protease from thermo alkalophilic Bacillus sp, JP-99. Bioresour. Technol, 82: 61-64.

Boominadhan, U., R. Rajkumar, P.K.V. Sivakumaar and M.M. Joe. 2009. Optimization of Protease enzyme production using Bacillus Sp. Isolated from different wastes, Botany Res. 
Int., 2(2): 83-8.

Kumar, D., N. Savitri, R. Thakur, K. Verma and T.C. Bhalla. 1999. Microbiol protease and application as laundry detergent additive, Res. J. Microbiol., 3: 661-672.

Singh, J., R. Vohra, M. Sahoo. 2001. Purification and characterization of two extracellular alkaline proteases from a newly isolated obligate alkalophilic Bacillus sphaericus, $J$. Industrial Microbiol. Biotechol., 26: 387-93.

Abu Sayem Alam, S.M., M.J. Hoq M.dM. 2006. Effect of temperature, $\mathrm{pH}$ and metal ions on the activity and stability of alkaline protease from novel Bacillus licheniformis MZK03, Proc. Pak. Acad. Sci., 43(4): 257-262.

Dodia, M.S., R.H. Joshi, R.K. Patel, S.P. Singh. 2006. Characterization and stability of extracellular alkaline proteases from halophilic and alkaliphilic bacteria isolated from saline habitat of coastal Gujarat, India. Brazil, J. Microbiol., 37: 276-282.

Abou Elalla, F.M., E.M. Shalab. 2009. Antioxidant activity of extract and semi-purified fractions of Marine Red
Macroalgae, Garcilaria verrucosa. Austral. J. Basic Appl. Sci., 3(4): 3179-3185.

Nehra, K.S., S. Dhillon, K. Chaudhary and R. Singh. 2002. Production of alkaline protease by Aspergillus species under submerged and solid state fermentation. Ind. J. Microbiol, 42: 43-47.

Srinivas Naik, L. 2013. Isolation and Biochemical characterization of protease isolated from Bacillus $\mathrm{sp}$ SVN12, Int. J. Res. Pure and Appl. Microbiol., 3(3): 94-10.

Feroz Khan, New microbial proteases in leather and detergent industries, Innov. Res. Chem., 1: 1-6.

Panagal Mani, T.M.M., John Bastin, R. Arun Kumar, B. Lalithambikai, B. Brintha, E. Surya Prabha, R. Rinikarunya, R. Manignodan, C. Marimuthu, and V. Ramesh Kannan. 2012. Thermo stable alkaline protease from thermo philic and alkaliphilic Bacillus licheniformis and its application as a laundry additive, Int. J. Med. Biosci., 1(3): 18-26.

\section{How to cite this article:}

Hala Ezzat Abou El-Hassayeb and Samaa M.Z. Abdel Aziz. 2016. Screening, Production and Industrial Application of Protease Enzyme From Marine Bacteria. Int.J.Curr.Microbiol.App.Sci. 5(7): 863-874. doi: http://dx.doi.org/10.20546/ijcmas.2016.507.099 